\title{
Pengaruh Kualitas Pelayanan Dan Kepuasan Pelanggan Terhadap Loyalitas Pelanggan Pada Pasar Tradisional Ngronggo Kota Kediri
}

\author{
Nelly Novia S; Sasi Utami; Rinto Nurbambang \\ Fakultas Ekonomi - Universitas Kadiri \\ E-mail : sasi@unik-kediri.ac.id
}

\begin{abstract}
The development of international business is growing very rapidly followed by the development of more sophisticated technologies. Where the development between businesses is supported by the development of sophisticated technology so that it can create a very high quality business. One of the changes that is taking place at this time is a change in the mindset of the people towards their desired needs. Changes in mindset in the community become a reference for the business world to create a variety of products and brands. In the era of globalization that occurs in the business world, the number of competing brands and products is increasing faster. One sampling technique uses Purposive Sampling. Purposive Sampling is a technique of determining samples with certain considerations. Respondents in this study were Ngronggo Kota Kediri traditional market customers, amounting to 40 respondents. The characteristics of each respondent are: age, gender, and frequency of visits. This data aims to describe the conditions or conditions of respondents so that researchers are easy to get information and understand the results of research. The Multiple Linear Regression Test shows that the regression results obtained coefficient for the Service Quality variable (X1) of 0.215 , and the Customer Satisfaction variable (X2) of 0.442 with a constant of -1.985.
\end{abstract}

Keywords: Service Quality, Customer Satisfaction, Customer Loyalty

\begin{abstract}
ABSTRAK
Perkembangan bisnis internasional berkembang sangat pesat diikuti pula dengan berkembangnya teknologi yang lebih canggih. Dimana perkembangan antara bisnis didukung oleh perkembangan teknologi yang canggih sehingga dapat tercipta kualitas bisnis yang sangat maksimal. Salah satu perubahan yang terjadi saat ini adalah perubahan pola pikir masyarakat terhadap kebutuhan yang diinginkan. Perubahan pola pikir pada masyarakat menjadi referensi dunia bisnis untuk menciptakan berbagai macam produk dan merek. Dalam era globalisasi yang tejadi dalam dunia bisnis, jumlah merek dan produk yang bersaing meningkat lebih cepat. Salah satu teknik pengambilan sampel menggunakan jenis Purposive Sampling. Purposive Sampling adalah teknik penentuan sampel dengan pertimbangan tertentu. Responden dalam penelitian ini adalah pelanggan pasar tradisional Ngronggo Kota Kediri yang berjumlah 40 orang responden. Adapun beberapa karakteristik masing-masing responden yaitu : usia, jenis kelamin, dan frekuensi berkunjung. Data ini bertujuan untuk menggambarkan keadaan atau kondisi responden sehingga peneliti mudah dalam mendapatkan informasi dan memahami hail-hasil penelitian. Uji Regresi Linier Berganda diketahui hasil regresi diperoleh koefesien untuk variabel Kualitas Pelayanan $\left(X_{1}\right)$ sebesar 0,215, dan variabel Kepuasan Pelanggan $\left(X_{2}\right)$ sebesar 0,442 dengan konstanta sebesar -1,985.
\end{abstract}

Kata Kunci : Kualitas Pelayanan, Kepuasan Pelanggan, Loyalitas Pelanggan 


\section{PENDAHULUAN}

Perkembangan bisnis internasional berkembang sangat pesat diikuti pula dengan berkembangnya teknologi yang lebih canggih. Dimana perkembangan antara bisnis didukung oleh perkembangan teknologi yang canggih sehingga dapat tercipta kualitas bisnis yang sangat maksimal. Salah satu perubahan yang terjadi saat ini adalah perubahan pola pikir masyarakat terhadap kebutuhan yang diinginkan. Perubahan pola pikir pada masyarakat menjadi referensi dunia bisnis untuk menciptakan berbagai macam produk dan merek. Dalam era globalisasi yang tejadi dalam dunia bisnis, jumlah merek dan produk yang bersaing meningkat lebih cepat. Namun dengan adanya persaing yang terjadi di pasar saat ini sangat membantu masyarakat dalam memilih berbagai kebutuhan yang diinginkan oleh para pelanggan. Sehingga menuntut para pelaku bisnis untuk mengeluarkan seluruh kemampuan yang mereka miliki untuk memenuhi kebutuhan para pelanggan.

Globalisasi membawa masyarakat Indonesia pada perkembangan yang lebih maju. Kebutuhan yang meningkat menjadi acuan dasar untuk para pelaku bisnis di pasar Indonesia dalam memenuhi permintaan pelanggan. Kebutuhan pelanggan yang terpenuhi dengan benar akan menciptakan kepuasan tersendiri. Kepuasan tersebut biasa disebut dengan Kepuasan Pelanggan. Dalam pasar Indonesia kepuasan pelanggan menjadi pokok penting dalam mempertahankan para pelanggan. Kepuasan pelanggan dalam hal pelayanan para pedagang dan kualitas barang yang diinginkan cenderung berpengaruh pada tingkat loyalitas para pelanggan.

Kepuasan pelanggan (konsumen) adalah suatu anggapan yang dirasakan atau disampaikan pelanggan kepada pedagang (produsen) dimana pedagang tersebut dapat memaksimalkan kualitas barang yang diminta pelanggan maupun kualitas pelayanan yang disampaikan oleh pedagang. menyatakan bahwa secara tradisional pengertian puas dan ketidakpuasan pelanggan merupakan perbedaan antara harapan, persepsi atau kinerja yang dirasakan. Kepuasan merupakan penilaian mengenai isi atau keistimewaan produk jasa atau produk itu sendiri, yang menyediakan tingkat kesenangan pelanggan berkaitan dengan pemenuhan kebutuhan konsumsi pelanggan. Kepuasan dalam hal ini adalah kepuasan yang mencakup kepuasan pelanggan di pasar tradisonal. Kepuasankepuasan tersebut muncul setelah melakukan perbandingan di beberapa penjual yang berbeda atau bahkan ditempat yang berbeda pula. Kepuasaan pelanggan antara 
pelanggan satu dengan pelanggan yang lainnya pun berbeda-beda (Yunanto, 2017). Contohnya kepuasan pelanggan A sangat berpengaruh karena pelayanan yang diberikan pedagang sangat berkualitas dan produk yang diminta juga memenuhi kriteria permintaan pelanggan, sehingga pelanggan A terus menaruh kepercayaan pada pedagang tersebut, sedangkan kepuasan pelanggan B hanya berpengaruh karena pelayanan yang diberikan tetapi produk yang diminta kurang sesuai, sehingga pelanggan B belum sepenuhnya menaruh kepercayaan kepada pedagang tersebut.

Dengan adanya contoh tersebut dapat disimpulkan bahwa kepuasan pelanggan merupakan salah satu faktor yang sangat penting dalam mempertahankan loyalitas pelanggan. Kepuasan pelanggan dapat memicu seorang pelanggan menjadi pelanggan yang loyal. Kembali lagi dapat disimpulkan bahwa pelanggan yang setia atau pelanggan yang loyal adalah pelanggan yang sangat puas dengan hasil kinerja para pedagang dalam bersaing di dunia pasar.

Ketatnya persaingan bisnis dalam dunia pasar, menuntut para pedagang dipasar harus dapat menjaga loyalitas pelanggan agar tetap setia terhadap pedagang tersebut. Mengapa dikatakan hal seperti itu, karena menjaga loyalitas pelanggan lebih penting dari pada menyusun strategi baru yang lebih agresif hanya untuk memperoleh pelanggan yang potensial. Beberapa ahli mendefinisikan pengertian loyalitas pelanggan seperti menyatakan loyalitas (loyalty) sebagai "komitmen yang dipegang secara mendalam untuk membeli atau mendukung kembali produk atau jasa yang disukai dimasa depan meski pengaruh situasi dan usaha pemasaran berpotensi menyebabkan pelanggan beralih”. Mengapa para pedagang (produsen) dituntut untuk selalu menjaga loyalitas pelanggan? Karena ketika pelanggan banyak yang kembali ketempat semula, berarti pelanggan tersebut puas dengan apa yang sudah diberikan, maka dari itu pelanggan tersebut dikatakan sangat loyal terhadap pedagang tersebut. Contohnya, seorang pelanggan berkomitmen pada suatu merek produk tas hingga pelanggan tersebut sangat loyal terhadap pedagang yang menjual tas tersebut. Bukan karena hal yang lain, mungkin karena kualitas pelayanan yang sangat baik dari para pedagang, kemudian produk yang diminta sangat berkualitas dan sesuai dengan yang diminta pelanggan. Sehingga pelanggan tersebut sangat percaya dengan merek atau brand tersebut. Dengan demikian, hal tersebut menyebabkan para pelanggan tersebut tetap percaya menggunakan produk tersebut. 
Contoh tersebut dapat menjelaskan bahwa menjaga loyalitas pelanggan sangatlah penting. Karena loyalitas pelanggan merupakan salah satu hal pokok yang wajib dilakukan oleh para pelaku bisnis untuk tetap mempertahankan pelanggan. Sehingga dapat dikatakan kepuasan pelanggan dan loyalitas pelanggan sangat berpengaruh besar terhadap kelangsungan usaha. Apalagi untuk usaha yang ada di pasar tradisional.dalam hal ini loyalitas pelanggan merupakan suatu wujud dari seorang pelanggan yang merasa dirinya sangat puas pada hasil kinerja yang diberikan oleh pelaku bisnis dalam pasar. Oleh karena itu, pelaku bisnis dalam pasar dituntut untuk senantiasa memberikan kinerja yang sesuai atau bahkan lebih kepada para pelanggan agar kepuasan pelanggan tercipta secara signifikan. Adapun faktor lain yang dapat mempengaruhi kepuasan pelanggan yaitu faktor kualitas pelayanan. Konsumen yang merasa puas terhadap produk/ layanan akan cenderung loyal terhadap produk/ layanan tersebut (Putra \& Ruhamak, 2017)

Kualitas pelayanan merupakan salah satu faktor utama yang membentuk kepuasan pelanggan sehingga tercipta suatu loyalitas pelanggan . Menyatakan bahwa kualitas pelayanan atau kualitas jasa merupakan ukuran seberapa bagus tingkat layanan yang diberikan mampu sesuai ekspektasi pelanggan. Kualitas yang diberikan para pelaku bisnis dalam pasar juga sangat berbeda-beda. Dan juga cara mengukur kualitas pelayanan pelanggan oleh pelanggan terhadap pelaku bisnis dalam pasar juga sangat beragam. Dalam hal ini kualitas pelayanan di pasar tradisional juga sangat berbeda dengan kualitas pelayanan di pasar modern. Kelengakapan mengenai produk, harga dan kecanggihan teknologi juga ikut berpengaruh terhadap kualitas. Dalam pembahasan kualitas pelayanan dapat dibedakan menjadi 2, yaitu : kualitas pelayanan yang baik dan kualitas pelayanan yang buruk. Kualitas pelayanan yang baik adalah suatu upaya yang dilakukan para pelaku bisnis dalam pasar untuk mempertahankan para pelanggannya. Sedangkan, kualitas pelayanan yang buruk merupakan salah satu bentuk atau cara yang mungkin secara tidak langsung dapat membuat para pelanggan merasa kecewa dengan produk maupun jasa yang ditawarkan. Dapatkan dikatakan sebagai pelayanan yang kurang memuaskan atau tidak sesuai dengan ekspektasi para pelanggan sebelumnya.

Kualitas pelayanan tidak selalu berjalan konstan atau permanen, tetapi kualitas pelayanan berjalan secara berubah-berubah atau lebih tepatnya dikatakan bersifat fleksibel (Gandung Satriyono \& Desi Kristanti, 2018). Dan tentunya perubahan ini akan 
berorientasi pada peningkatan pelayanan yang lebih baik. Mengapa demikian? Karena, kualitas pelayanan dapat diartikan sebagai tingkat kepuasan para pelanggan. Tingkat kepuasan para pelangga ini diperoleh dari beberapa perbandingan pelayanan secara nyata yang diterima langsung oleh para pelanggan. Jika pelayanan yang diberikan melampaui batas, maka pelayanan tersebut dapat dikategorikan sebagai pelayanan yang sangat berkualitas atau sangat memuaskan para pelanggannya. Kualitas sangat penting dan berpengaruh terhadap kelangsungan usaha karena kualitas pelayanan berdampak secara langsung pada citra atau nama baik usaha para pelaku bisnis dipasar.

Pasar adalah tempat atau lokasi berkumpulnya beberapa pedagang dan beberapa pembeli yang sedang atau akan melakukan transaksi jual beli barang atau produk yang akan diperjual belikan ditempat tersebut. Berdasarkan cara transaksinya pasar dibedakan menjadi 2, yaitu : pasar moderen dan pasar tradisional. Pasar moderen merupakan tempat antara penjual dan pembeli, dimana tidak terjadi tawar menawar dan harga yang diberikan sudah tertera serta produk yang diperjual belikan sudah dijamin berkualitas lebih unggul. Pasar moderen biasanya atau bahkan dominan terletak di daerah perkotaan. Contoh beberapa pasar moderen antara lain : Hypermart, Matahari department Store, Ramayana, Carrefour dan lain-lain. Sedangkan pasar tradisional merupakan tempat bertemunya antara penjual dan pembeli, dimana terjadi proses tawar menawar diantara keduanya untuk memperoleh kesepakatan bersama dalam proses jualbeli produk. Produk yang ditawarkan di pasar tradisional juga belum tentu berkualitas unggul. Biasanya produk yang ditawarkan merupakan bahan kebutuhan pokok.

Seperti halnya salah satu pasar tradisional yang berada dan beroperasi di Kota Kediri, yaitu pasar tradisional Ngronggo Kota Kediri. Pasar tradisional Ngronggo Kota Kediri merupakan salah satu pasar tradisional milik pemerintah Kota Kediri. Pasar tradisional Ngronggo Kota Kediri juga dikelola pemerintah Kota Kediri dan di tempati oleh para pedagang yang berasal dari beberapa daerah. Sama seperti pasar-pasar tradisional yang lain, pasar Ngronggo Kota Kediri dijalankan untuk kelangsungan hidup dan perkembangannya dapat terpelihara dengan baik dan benar. Sebagai salah satu pasar tradisional yang terdapat di Kota Kediri, pasar Ngronggo bukan hanya pasar hanya dikunjungi oleh para pelanggan, tetapi juga dijadikan pelanggan sarana untuk sekedar berjalan-jalan saja. Tujuan utama para pedagang di pasar Ngronggo Kota Kediri adalah memberikan pelayanan dan kepuasan yang maksimal pada pelanggan atau pengunjung 
pasar, khususnya para pelanggan daerah Kediri. Para pedagang dituntut untuk memahami situasi dan kondisi, dimana situasi dan kondisi tersebut harus bersaing dengan para pedagang di pasar tradisional Ngronggo Kota Kediri, di pasar-pasar daerah Kota Kediri atau bahkan bersaing dengan pasar Moderen yang berdiri di Kota Kediri. Situasi dan kondisi tersebut yang mendorong para pedagang di pasar tradisional Ngronggo Kota Kediri untuk memberikan kualitas pelayanan dan kepuasan yang terbaik dan maksimal kepada para pelanggan atau pengunjung pasar

\section{TINJAUAN PUSTAKA}

\section{Kualitas Pelayanan}

Menurut Yamit (2010) menuturkan mengenai definisi dari kualitas. Kualitas dapat berbeda makna bagi setiap orang, karena kualitas mempunyai banyak kriteria atau ciriciri yang sangat tergantung pada konteksnya. Beberapa pakar dibidang kualitas mencoba untuk mendefinisikan beberapa pengertian mengenai kualitas berdasarkan sudut pandangnya masing-masing. Menurut Kotler (2016) pelayanan merupakan setiap tindakan atau kegiatan yang dapat ditawarkan oleh suatu pihak kepada pihak lain, pada dasarnya tidak berwujud dan tidak mengakibatkan kepemilikan apapun. Menurut Mauludin (2010:67) mengemukakan bahwa kualitas pelayanan adalah seberapa jauh perbedaan antara kenyataan dan harapan pelanggan atas langganan yang mereka terima atau peroleh.

Aksa (2011:107), kualitas pelayanan adalah seberapa jauh perbedaan antara kenyataan dan harapan pelanggan atas pelayanan yang diterima atau diperoleh. Setyanto (2010) mengatakan bahwa kualitas pelayanan merupakan suatu kondisi dinamis yang berhubungan dengan produk, jasa, manusia, proses, dan lingkungan yang memenuhi atau melebihi harapan. Sedangkan menurut Tjiptono (2010) kualitas pelayanan adalah tingkat keunggulan yang diharapkan dan pengendalian atas tingkat keunggulan tersebut untuk memenuhi keinginan pelanggan. Pengertian kualitas menurut Tjiptono (2011) bahwa kualitas terdiri dari beberapa aspek antara lain :
a. Kesesuaian dengan kecocokan atau tuntutan;
b. Kecocokan untuk pemakaian;
c. Perbaikan atau penyempurnaan berkelanjutan;
d. Bebas dari kerusakan atau cacat; 
e. Pemenuhan kebutuhan pelanggan sejak awal dan setiap saat;

f. Melakukan segala sesuatu secara benar sejak awal;

g. Sesuatu yang bisa membahagiakan pelanggan.

\section{Kepuasan Pelanggan}

\section{Definisi Kepuasan Pelanggan}

Banyak pakar yang berusaha mendefenisikan kepuasan pelanggan berdasarkan perspektifnya masing-masing. Namun pada intinya mereka menyatakan substansi yang sama tentang kepuasan pelanggan. Kotler dan Keller (2012) menyatakan bahwa kepuasan pelanggan (konsumen) adalah perasaan senang atau kecewa seseorang yang muncul setelah membandingkan antara kinerja (hasil) produk yang dipikirkan terhadap kinerja (hasil) yang diharapkan. Jika kinerja berada dibawah harapan, maka pelanggan dikatakan tidak puas. Jika kinerja memenuhi harapan, maka pelanggan dikatakan puas. Jika kinerja melebihi harapan, pelanggan dikatakan amat puas atau senang.

Menurut Lupiyoadi (2013) kepuasan pelanggan didefenisikan sebagai respon pelanggan terhadap ketidaksesuaian antara tingkat kepentingan sebelumnya dan kinerja aktual yang di rasakan setelah pemakaian. Zeithaml dan Bitner (2008) menyatakan bahwa secara tradisional pengertian kepuasan atau ketidakpuasan konsumen merupakan perbedaan antara harapan (expectation) dan persepsi atau kinerja yang dirasakan (perceived performance). Solomon (2011) menyatakan bahwa kepuasan pelanggan (konsumen) adalah suatu perasaan keseluruhan pelanggan mengenai produk atau jasa yang telah dibeli oleh pelanggan. (Engel et Al., 2010) menyatakan bahwa kepuasan pelanggan merupakan evaluasi purna beli dimana alternativ yang dipilih sekurangkurangnya memberi hasil atau (outcome) yang sama atau melebihi harapan dari pelanggan, sedangkan ketidakpuasan akan timbul apabila hasil yang diperoleh tidak memenuhi harapan pelanggan.

\section{Dimensi Kepuasan Pelanggan}

Adapun beberapa faktor yang mempengaruhi kepuasan pelanggan menurut (Tjiptono, F dan Candra, 2011) antara lain :

a. Produk 
Layanan produk yang baik dan memenuhi standarisasi atau memenuhi selera serta harapan pelanggan. Produk dapat menciptakan kepuasan tersendiri terhadap pelanggan. Dasar penilaian terhadap pelayanan produk ini meliputi : jenis produk, mutu atau kualitas dan kuantitas produk serta ketersediaan produk yang di tawarkan.

b. Harga

Harga atau price merupakan suatu nulai tukar yang bisa disamakan dengan uang atau barang lain untuk manfaat yang diperoleh dari suatu barang atau jasa bagi seseorang atau kelompok pada waktu tertentu dan tempat tertentu (Oentoro,D, 2012). Dasar penilaian terhadap harga meliputi tingkat harga dan kesesuaian dengan nilai jual produk, variasi atau pilihan harga terhadap produk.

c. Promosi

Promosi merupakan suatu hal mengenai informasi produk dan jasa perusahaan dalam usaha mengomunikasikan manfaat produk dan jasa tersebut pada sasaran pelanggan.

d. Lokasi

Lokasi atau tempat merupakan bagian dari atribut perusahaan (usaha) yang berupa lokasi perusahaan (usaha) dan pelanggan. Penilaian terhadap atribut lokasi meliputilokasi perusahaan (usaha), kecepatan dan ketepatan dalam hal transportasi.

e. Pelayanan karyawan

Pelayanan karyawan merupakan pelayanan yang diberikan karyawan dalam usaha memenuhi kebutuhan dan keinginan pelanggan (konsumen) dalam usaha memuaskan pelanggan. Dasar penilaian dari pelayanan karyawan meliputi kesopanan, keramahan, kecepatan dan ketepatan dalam menghadapi permintaan para pelanggan.

f. Fasilitas

Fasilitas merupakan bagian dari atribut perusahaan yang berupa perantara guna mendukung kelancaran operasional perusahaan yang berhubungan dengan pelanggan (konsumen). Penilaian fasilitas meliputi penataan barang, tempat penitipan barang, kamar kecil dan tempat ibadah.

g. Suasana 
Suasana merupakan faktor pendukung, karena apabila perusahaan mengesankan maka pelanggan akan mendapatkan kepuasan tersendiri. Dasar penilaian suasana meliputi sirkulasi udara, kenyamanan dan keamanan.

\section{Loyalitas Pelanggan}

\section{Definisi Loyalitas Pelanggan}

Loyalitas pelanggan adalah suatu komitmen jangka panjang seorang pelanggan yang terwujud dalam perilaku dan sikap yang loyal terhadap suatu perusahaan (pasar) dan produknya, dengan cara mengkonsumsi secara teratur dan berulang. Sehingga perusahaan (pasar) dan produknya menjadi bagian penting dari proses konsumsi yang dilakukan oleh para pelanggan. Terdapat beberapa teori mengenai loyalitas pelanggan yang mendukung penelitian tentang loyalitas pelanggan. Menurut Kotler (2012) mendefenisikan loyalitas pelangaan sebagai komitmen yang dipegang secara mendalam untuk membeli atau mendukung kembali produk atau jasa yang disukai dimasa depan meski pengaruh situasi dan usaha pemasaran berpotensi menyebabkan pelanggan beralih.

Tjiptono dan Candra (2011) menyatakan bahwa loyalitas pelanggan (customer loyalty) adala komitmen pelanggan terhadap suatu merek,toko, atau pemasok, yang tercermin dari sikap (attitude) yang sangat positif dan wujud perilaku (behavior) pembelian ulang yang dilakukan oleh pelanggan tersebut secara konsisten. Scott Robinette dan Claire Brand (2011) menyatakan bahwa loyalitas pelanggan merupakan satu-satunya alasan yang sangat penting untuk meraih keuntungan karena berhubungan langsung dengan keuntungan yang akan diraih oleh perusahaan.

\section{Dimensi Loyalitas Pelanggan}

Menurut Tjiptono, Loyalitas pelanggan dapat dilihat dari beberapa indikator, yaitu:

a. Pembelian Berulang

Pembelian berulang merupakan bentuk dari kepuasan pelanggan terhadap produk atau jasa yang diterima oleh pelanggan. pembelian ulang dapat dijadikan sebagai promosi yang terus-menerus dalam rangka memikat atau membujuk pelanggan untuk membeli produk dan merk yang sama. Dengan indikator keinginan untuk membeli lagi. 
b. Memberikan Referensi kepada Orang Lain

Pelanggan yang loyal akan berpotensi untuk menyebarkan atau menjadi word of mouth advertiser bagi perusahaan. Dengan indikator merekomendasikan kepada orang lain.

c. Penolakan terhadap Produk Pesaing (Kesetiaan)

Pelanggan yang setia terhadap suatu produk atau merk akan cenderung terikat pada produk atau merk tersebut. Sehingga para pelanggan akan kembali membeli produk atau merk tersebut ditempat yang sama meskipun ada banyak alternatif lain dalam menentukan pilihan. Dengan indikator keinginan untuk tidak berpindah tempat berbelanja.

\section{Keuntungan Pelanggan Yang Loyal}

Kertajaya (2014) merangkum butir-butir pemikiran Fedrick Reicheld tetang loyalitas konsumen dalam lingkungan bisnis yang semakin turbulen dan ditengah psatnya perkembangan teknologi informasi sebagai berikut

a. Loyalitas konsumen adalah jaminan keunggulan bersaing, pertumbuhan, laba dan tentu saja sustainility jangka panjang perusahaan. Karena itu, retensi konsumen merupakan sebuah indikator yang mencerminkan gabungan dari keseluruhan dimensi bisnis sebuah perusahaan dalam menciptakan nilai ;

b. Bahkan loyalitas konsumen merupakan indikator yang lebih handal daripada laba daalam mengukur kemampuan perusahaan dalam menciptakan nilai ;

c. Survei menunjukkan bahwa penambahan tingkat retensi konsumen sebesar 5\% saja dapat meningkatkan laba antara $25 \%$ sampai $90 \%$

\section{METODE PENELITIAN}

\section{Populasi Penelitian}

Populasi adalah wilayah generalisasi yang terdiri atas obyek atau subyek yang mempunyai kualitas dan karakteristik tertentu yang ditetapkan oleh peneliti untuk dipelajari dan kemudian ditarik kesimpulannya (Sugiyono, 2016) .Populasi pada penelitian ini adalah pelanggan (pembeli) pada pasar Ngronggo Kota Kediri.

\section{Sampel Penelitian}


Sampel adalah bagian dari jumlah dan karakteristik yang dimiliki oleh populasi (Sugiyono, 2016). Sampel pada penelitian ini adalah sebagian pelanggan pasar Ngronggo Kota Kediri yang dapat mewakili dalam penelitian ini. Untuk menentukan ukuran sampel penelitian dari populasi tersebut dapat digunakan rumus 15 atau $20 \mathrm{x}$ variabel bebas (Joseph F.Hair, 1998), jadi akan dapat hasil sebagai berikut :

$20 \times 2$ (jumlah variabel bebas) $=40$

\section{Teknik Pengambilan Sampel}

Teknik pengambilan sampel menggunakan Nonprobability Sampling. Menurut (Sugiyono, 2016:125) Nonprobability Sampling adalah teknik pengambilan sampel yang tidak memberi peluang atau kesempatan sama bagi setiap unsur atau anggota populasi untuk dipilih menjadi sampel. Salah satu teknik pengambilan sampel menggunakan jenis Purposive Sampling. Purposive Sampling adalah teknik penentuan sampel dengan pertimbangan tertentu.

\section{Definisi Operasional}

Definisi operasional variabel adalah gambaran variabel yang akan diperlukan guna mempermudah sebuah penelitian. Variabel merupakan sesuatu yang berbentuk apa saja yang ditetapkan oleh seorang peneliti untuk dipelajari sehingga diperoleh informasi mengenai hal yang akan diteliti.

\section{Metode Pengumpulan Data}

\section{Jenis Data}

Jenis data yang digunakan dalam penelitian ini adalah jenis data Kuantitatif. Jenis data kuantitatif dalam penelitian ini adalah jenis data yang diperoleh melalui kuesioner yang telah dibagikan kepada sebagian pelanggan pasar tradisional Ngronggo Kota Kediri.

\section{Sumber Data}

Sumber data yang digunakan dalam penelitian ini menggunakan data primer. Menurut Santoso dan Tjiptono (2009:58), menyatakan bahwa data primer adalah data yang diolah sendiri oleh suatu organisasi atau perorangan langsung dari objeknya. Data primer tersebut merupakan data yang langsung diambil dari sumbernya.

\section{Teknik Pengumpulan Data}


Adapun teknik pengumpulan data dalam penelitian ini adalah sebagai berikut :

1. Observasi

Dalam penelitian ini, peneliti menggunakan jenis Observasi Berperanserta (participant Observation) yaitu peneliti terlibat langsung dalam kegiatan sehari-hari mengenai pelanggan yang sedang diamati atau yang digunakan sebagai sumber data penelitian. (Sugiyono : 2016)

2. Kuesioner (Angket)

Kuesioner yaitu survei menggunakan angket pertanyaan atau pernyataan tertulis kepada pelanggan pasar Ngronggo Kota Kediri guna untuk memperoleh informasi yang diperlukan tanpa adanya kekhawatiran dalam pemberian jawaban. Kuesioner atau angket juga merupakan daftar pertanyaan yang diberikan kepada orang lain yang bersedia memberikan respon sesuai dengan permintaan penggunaan (Hasan, 2009:83)

3. Wawancara

Wawacara yaitu pengumpulan data dengan cara bertanya secara langsung kepada pemilik agar informasi yang diperoleh lebih akurat (Sugiyono, 2016:194). Hasil dari wawancara tersebut diperoleh tentang gambaran umum pasar Ngronggo Kota Kediri beserta dengan para pelanggannya.

\section{Analisis Regresi Linier Berganda}

Analisis regresi berganda digunakan dalam penelitian ini karena variabel independen dalam penelitian ini lebih dari satu. Analisis regresi linier berganda adalah regresi dimana variabel terikat (Y) dihubungkan atau dijelaskan lebih dari satu variabel, bisa tiga dan seterusnya variabel bebas $\left(\mathrm{X}_{1}, \mathrm{X}_{2}, \mathrm{X}_{3}, \ldots \ldots \ldots \mathrm{X}_{\mathrm{n}}\right)$ namun masih menunjukkan diagram hubungan yang linier (Sholihin, 2013).

Pengguna metode analisis ini untuk menganalisis pengaruh kualitas pelayanan terhadap loyalitas pelanggan dan pengaruh kepuasan pelanggan terhadap loyalitas pelanggan

\section{Uji Hipotesis}

Mengukur besarnya pengaruh variable bebas terhadap variable terikat dan juga untuk mengatur keeratan hubungan $\mathrm{X}$ dan $\mathrm{Y}$. Uji hipotesis yang digunakan dalam 
penelitian ini ada tiga, yaitu uji koefesien determinasi $\left(\mathrm{R}^{2}\right)$, uji $\mathrm{F}$ (Simultan), dan uji $\mathrm{t}$ (parsial).

\section{Koefesien Determinasi $\left(\mathbf{R}^{2}\right)$}

Koefesien Determinasi $\left(\mathrm{R}^{2}\right)$ mengukur sebarapa jauh model dalam menerangkan variasi variabel dependen. Nilai koefesien determiasi adalah antara 0 dan 1 (Ghozali, 2011:97). Nilai $\mathrm{R}^{2}$ yang kecil berarti kemampuan variabel-variabel independen dalam menjelaskan variasi variabel dependen sangat terbatas. Nilai yang mendekati 1 berarti variabel-variabel independen memberikan hampir seluruh informasi yang dibutuhkan untuk memprediksi variasi variabel dependen. Secara umum koefesien determinasi untuk data silang (cross section) relatif mudah karena ada variasi yang besar antar masing-masing pengamatan. Nilai koefesien determinasi mempunyai interval nol sampai satu $\left(0 \mathrm{R}^{2} \leq\right)$. Jika $R^{2}=1$, berarti besar presentase sumbangan $X_{1}$ dan $X_{2}$ terhadap variasi (naik-turunya) $\mathrm{Y}$ secara bersama-sama adalah 100\%. Hal ini menunjukkan bahwa apabila koefesien determinasi mendeteksi 1, maka pengaruh variabel independen terhadap variabel dependen semakin kuat, maka semakin cocok pula garis regresi untuk meramalkan Y.

\section{HASIL PENELITIAN DAN PEMBAHASAN}

\section{Uji Analisis Regresi Linier Berganda}

\section{Hasil Analisis Regresi Linier Berganda}

\begin{tabular}{|c|c|c|c|c|c|}
\hline \multirow[b]{2}{*}{ Model } & \multicolumn{2}{|c|}{$\begin{array}{l}\text { Unstandardized } \\
\text { Coefficients }\end{array}$} & \multirow{2}{*}{$\begin{array}{c}\begin{array}{c}\text { Standardized } \\
\text { Coefficients }\end{array} \\
\text { B eta }\end{array}$} & \multirow[b]{2}{*}{$\mathbf{t}$} & \multirow[b]{2}{*}{ Sig. } \\
\hline & B & Std. Error & & & \\
\hline (Constant) & $-1,985$ & 2,435 & &,- 815 & ,420 \\
\hline Kualitas Pelayanan (X1) & ,215 & ,111 & ,409 & 1,937 &, 060 \\
\hline Kepuasan Pelanggan (X2) & ,442 & ,277 & ,336 & 1,593 &, 120 \\
\hline
\end{tabular}

a. Dependent Variable: Loyalitas Pelanggan $(\mathrm{Y})$

Sumber : Data Primer Diolah Oleh Peneliti (2019)

Berdasarkan hasil output SPSS tabel 4.17 dapat diketahui hasil regresi diperoleh koefesien untuk variabel Kualitas Pelayanan $\left(\mathrm{X}_{1}\right)$ sebesar 0,215, dan variabel Kepuasan Pelanggan $\left(\mathrm{X}_{2}\right)$ sebesar 0,442 dengan konstanta sebesar $-1,985$ sehingga model persamaan regresi yang diperoleh adalah sebagai berikut : 
$Y=-1,985+0,215 X 1+0,442 X 2$

Dimana :

$\mathrm{Y}=$ Loyalitas pelanggan

$\mathrm{X}_{1}=$ Kualitas pelayanan

$\mathrm{X}_{2}=$ Kepuasan pelanggan

Hasil analisis menggunakan bantuan program SPSS sebagai berikut :

1. Konstanta sebesar $-1,985$ menyatakan bahwa jika kualitas pelayanan dan kepuasan pelanggan bernilai 0 (nol), maka loyalitas pelanggan pada pasar tradisional Ngronggo Kota Kediri sebesar -1,985.

2. Pengaruh Kualitas Pelayanan $\left(\mathrm{X}_{1}\right)$ terhadap Loyalitas Pelanggan (Y) pada pasar tradisional Ngronggo Kota Kediri.

Hasil uji empiris pengaruh antara Kualitas pelayanan $\left(\mathrm{X}_{1}\right)$ terhadap Loyalitas Pelanggan (Y), menunjukkan nilai thitung 1,937 < $\mathrm{t}_{\text {tabel }} 2,021$ dan $\mathrm{p}$ value (Sig.) sebesar $0,60>0,05$. Artinya bahwa Kualitas Pelayanan $\left(X_{1}\right)$ tidak berpengaruh terhadap Loyalitas Pelanggan (Y) pada pasar tradisional Ngronggo Kota Kediri. Nilai beta dalam unstandardized coeffiients variabel Kualitas Pelayanan $\left(\mathrm{X}_{1}\right)$ melnunjukkan angka sebesar 0,409 yang artinya adalah besaran koefesien Kualitas Pelayanan terhadap Loyalitas Pelanggan adalah sebesar 40,9\%. Nilai t positif menunujukkan bahwa variabel kualitas pelayanan $\left(\mathrm{X}_{1}\right)$ memiliki hubungan yang searah dengan variabel loyalitas pelanggan (Y). Maka dapat diambil kesimpulan bahwa kualitas pelayanan ( $\left.\mathrm{X}_{1}\right)$ mempunyai hubungan yang positif tetapi tidak berpengaruh signifikan terhadap loyalitas pelanggan $(\mathrm{Y})$.

3. Pengaruh Kepuasan Pelanggan $\left(\mathrm{X}_{2}\right)$ terhadap Loyalitas Pelanggan $(\mathrm{Y})$ pada pasar tradisional Ngronggo Kota Kediri.

Hasil uji empiris pengaruh antara Kepuasan Pelanggan $\left(\mathrm{X}_{2}\right)$ terhadap Loyalitas Pelanggan (Y), menunjukkan nilai $t_{\text {hitung }} 1,593<\mathrm{t}_{\text {tabel }} 2,021$ dan $\mathrm{p}$ value (Sig.) sebesar $0,120>0,05$. Artinya bahwa Kepuasan Pelanggan $\left(\mathrm{X}_{2}\right)$ tidak berpengaruh terhadap Loyalitas Pelanggan (Y) pada pasar tradisional Ngronggo Kota Kediri. Nilai beta dalam unstandardized coeffiients variabel Kualitas Pelayanan $\left(\mathrm{X}_{1}\right)$ menunjukkan angka sebesar 0,336 yang artinya adalah besaran koefesien Kualitas Pelayanan terhadap Loyalitas Pelanggan adalah sebesar 33,6\%. Nilai t positif menunujukkan bahwa variabel kepuasan pelanggan $\left(\mathrm{X}_{2}\right)$ memiliki hubungan yang searah dengan variabel loyalitas pelanggan 
(Y). Maka dapat diambil kesimpulan bahwa kepuasan pelanggan $\left(\mathrm{X}_{2}\right)$ mempunyai hubungan yang positif tetapi tidak berpengaruh signifikan terhadap loyalitas pelanggan (Y).

\section{Pembahasan}

Berdasarkan hasil penelitian yang telah diuraikan untuk menjawab permasalahan "Pengaruh Kualitas pelayanan dan kepuasan pelanggan terhadap loyalitas pelanggan pada pasar tradisional Ngronggo Kota Kediri”. Dapat dilihat dari nilai signifikan $t_{\text {hitung }}>$ $t_{\text {tabel }}$ maka variabel bebas berpengaruh signifikan terhadap variabel terikat. Jika nilai signifikan $\mathrm{t}_{\text {hitung }}<\mathrm{t}$ tabel, maka variabel bebas tidak berpengaruh signifikan terhadap variabel terikat.

1. Pengaruh Kualitas pelayanan terhadap Loyalitas Pelanggan

Berdasarkan hasil analisis data diketahui bahwa nilai signifikansi uji $\mathrm{T}$ atau uji parsial sebesar 1,937 kurang dari $t_{\text {tabel }}$ adalah 2,021 dengan nilai signifikan 0,060 > 0,05. Maka dapat dikatakan variabel Kualitas pelayanan tidak berpengaruh signifikan terhadap loyalitas pelanggan pada pasar tradisional Ngronggo Kota Kediri. Artinya H1 ditolak. Hasil ini tidak sesuai dengan penelitian yang dilakukan oleh Henriawan (2015) yang menyatakan bahwa kualitas pelayanan berpengaruh signifikan terhadap loyalitas pelanggan pada toko cabang Mufin wilayah Bandung Timur). Meskipun begitu Henriawan (2015) menyatakan bahwa penyebab pengaruh antara kualitas pelayanan dan loyalitas pelanggan lemah. Berdasarkan hasil pengamatan dilapangan menunjukkan bahwa kualitas pelayanan tidak mempengaruhi loyalitas pelanggan. Hal tersebut disebabkan karena ada faktor-faktor lain yang memberikan pengaruh yang lebih kuat dalam menciptakan loyalitas pelanggan dibanding dengan faktor kualitas pelayanan. Kualitas pelayanan tidak berpengaruh penting dalam pencapaian loyalitas pelanggan pada pasar tradisional Ngronggo Kota Kediri. Hal ini disebabkan karena persepsi setiap responden terhadap kualitas pelayanan yang diterima tidak sesuai dengan yang diharapkan para pelanggan pasar tradisional Ngronggo Kota Kediri.

2. Pengaruh kepuasan pelanggan terhadap loyalitas pelanggan

Berdasarkan hasil analisis data diketahui bahwa nilai signifikansi uji $\mathrm{T}$ atau uji parsial sebesar 1,593 kurang dari tabel adalah 2,021 dengan nilai signifikan 0,120>0,05. Maka dapat dikatakan variabel kepuasan pelanggan tidak berpengaruh signifikan terhadap loyalitas pelanggan pada pasar tradisional Ngronggo Kota Kediri. Artinya H2 ditolak. Hasil ini tidak sesuai dengan penelitian yang dilakukan oleh Azkal (2016) yang menyatakan bahwa kualitas pelayanan berpengaruh positif dan signifikan terhadap 
loyalitas Mahasiswa Manajemen Dakwah Fakultas Dakwah Komunikasi Universitas Islam Negeri Sunan Kalijaga Yogyakarta. Berdasarkan hasil pengamatan dilapangan menunjukkan bahwa kepuasan pelanggan tidak mempengaruhi loyalitas pelanggan. Kepuasan pelanggan tidak berpengaruh signifikan dalam pencapaian loyalitas pelanggan pada pasar tradisional Ngronggo Kota kediri, hal ini disebabkan karena salah satu faktor penunjang kepuasan pelanggan (kualitas produk) tidak mendukung untuk pencapaian loyalitas pelanggan pada pasar tradisional Ngronggo Kota Kediri.

3. Pengaruh kualitas pelayanan dan kepuasan pelanggan terhadap loyalitas pelanggan

Selanjutnya untuk mengetahui pengaruh secara simultan dapat dilihat pada tabel

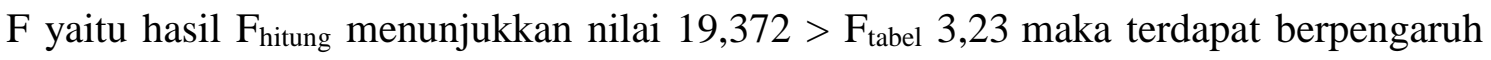
secara simultan variabel kualitas pelayanan dan kepuasan pelanggan terhadap loyalitas pelanggan pada pasar tradisional Ngronggo Kota Kediri. Hasil penelitian ini sama dengan penelitian sebelumnya yang dilakukan oleh Azkal (2016) yang menunjukkan bahwa kualitas pelayanan dan kepuasan pelanggan berpengaruh secara signifikan terhadap loyalitas berbelanja online di OLX.CO.ID studi pada Mahasiswa Manajemen dakwah fakultas dakwah dan komunikasi universitas islam Negeri Sunan Kalijaga Yogyakarta.

Dalam upaya mengidentifikasi seberapa jauh variabel independent berpengaruh terhadap variabel dependent, diperoleh nilai dari koefisien determinasi. Sebagaimana yg telah diuraikan sebelumnya, bahwa nilai koefisien determinasi ( $R$ Square) sebesar 0,512 atau sebesar 51,2 \% maka pengaruh variabel bebas terhadap variabel terikat lemah karena hal ini menunjukkan bahwa konstribusi variabel independen yaitu kualitas pelayanan dan kepuasan pelanggan yaitu sebesar $51,2 \%$ sedangkan sisanya dipengaruhi atau dapat dijelaskan oleh variabel lain diluar penelitian ini.

\section{KESIMPULAN DAN SARAN}

\section{Kesimpulan}

Berdasarkan hasil penelitian Pengaruh Kualitas Pelayanan dan Kepuasan pelanggan terhadap Loyalitas Pelanggan pada pasar tradisional Ngronggo Kota Kediri serta uraian dan penjelasan yang telah dikemukakan pada bab-bab sebelumnya, maka dapat ditarik kesimpulan sebagai berikut :

1. Uji Regresi Linier Berganda diketahui hasil regresi diperoleh koefesien untuk 
variabel Kualitas Pelayanan $\left(\mathrm{X}_{1}\right)$ sebesar 0,215, dan variabel Kepuasan Pelanggan $\left(\mathrm{X}_{2}\right)$ sebesar 0,442 dengan konstanta sebesar -1,985 sehingga model persamaan regresi yang diperoleh adalah sebagai berikut :

$Y=-1,985+0,215 X 1+0,442 X 2$

2. Secara parsial atau uji t menunjukkan bahwa kualitas pelayanan tidak berpengaruh secara signifikan terhadap loyalitas pelanggan. nilai $t_{\text {hitung }}=1,937$ yang artinya $t_{\text {hitung }}$ $<t_{\text {tabel }}(1,937<2,021)$ dengan signifikansi 0,60>0,05. Maka dapat diambil kesimpulan bahwa hipotesis pertama tidak terbukti.

3. Secara parsial atau uji t menunjukkan bahwa kepuasan pelanggan tidak berpengaruh secara signifikan terhadap loyalitas pelanggan. nilai $t_{\text {hitung }}=1,593$ yang artinya $t_{\text {hitung }}$ $<\mathrm{t}_{\text {tabel }}(1,593<2,021)$ dengan signifikansi 0,120>0,05 maka dapat diambil kesimpulan bahwa hipotesis kedua tidak terbukti.

4. Secara Simultan atau uji F menunjukkan bahwa kualitas pelayanan dan kepuasan pelanggan berpengaruh signifikan terhadap loyalitas pelanggan. $F_{\text {tabel }}$ sebesar 3,23. Karena nilai $F_{\text {hitung }}$ 19,372 lebih besar dari nilai $F_{\text {tabel. maka dapat diambil }}$ kesimpulan bahwa hipotesis ketiga terbukti.

\section{Saran}

Berdasarkan hasil penelitian, pembahasan, dan kesimpulan diatas, maka diajukan beberapa saran sebagai berikut :

1. Disarakan kepada pasar tradisional Ngronggo Kota Kediri untuk meningkatkan Kualitas Layanan dan Kepuasan Pelanggan sehingga Loyalitas Pelanggan pada pasar tradisional Ngronggo Kota kediri dapat tercipta dan dapat berpengaruh positif.

2. Untuk penelitian dimasa yang akan datang sebaiknya memperluas variabel dan pengukuran variabel penelitian sehingga dapat meningkatkan kualitas pelayanan dan kepuasan pelanggan terhadap loyalitas pelanggan.

\section{DAFTAR PUSTAKA}

Adisaputro, G. 2010. Manajemen Pemasaran. Unit Penerbit dan Percetakan Sekolah Tinggi Ilmu Manajemen YKPN (UPP STIM YKPN): Yogyakarta.

A.A. Ayu Atika Paramitha Wendha,dkk. 2013. Pengaruh kualitas layanan terhadap kepuasan dan loyalitas pelanggan Garuda Indonesia di Denpasar. Vol 7 No.1. .Jurnal Manajemen, strategi bisnis, dan Kewirausahaan.

Daryanto,dkk.2014.Perilaku dan pelayanan prima. Penerbit Gava Media: Yogyakarta.

Evan Chandra Kusuma. 2018. Pengaruh nilai yang diterima pelanggan dan kualitas pelayanan terhadap loyalitas pelanggan,kepuasan pelanggan sebagai mediator dan gender sebagai moderator(study pada PT KAI Kota Malang). Vol.50 No.1. Jurnal bisnis dan Manajemen. 
Gandung Satriyono \& Desi Kristanti. (2018). Pengaruh kepuasan pasien pada kualitas layanan Rawat Inap terhadap niat Discharge Against Medical Advice ( DAMA ) ( Studi di Rumah Sakit Umum Daerah Pare Kabupaten Kediri ). Ekonika, 3(2), 136153. https://doi.org/https://doi.org/10.30737/ekonika.v3i2.190

Ghozali, Imam. 2011. Aplikasi Analisis Multivariate dengan program IBM SPSS 19(edisi kelima). Semarang: Universitas Diponegoro.

Hanif Wahyu Widodo. 2016. Pengaruh kualitas pelayanan dan kepuasan pelanggan terhadap loyalitas pelanggan (study kasus di Nyaman Konveksi). Universitas Muhammadiyah Surakarta. Skripsi.

I Made Satya Graha,dkk. 2016. Pengaruh kualitas pelayanan terhadap kepuasan dan loyalitas pelanggan Hardy's Negara. Vol 5 No.2.309-33. E-jurnal Ekonomi dan Bisnis Universitas Udayana.

Lidia Sri Purwaningsih,dkk. 2018. Pengaruh kualitas pelayanan terhadap loyalitas pelanggan dengan kepuasan pelanggan sebagai variabel mediasi (survei pada pelanggan rias pengantin Putri Ayu di Surakarta).18 Edisi Khusus. 140-150. Jurnal Ekonomi dan Kewirausahaan.

Muhammad Maskur,dkk. 2016. Analisis pengaruh kualitas pelayanan,harga,dan kepuasan pelanggan terhadap loyalitas pelanggan(study kasus pada bengkel mobil Larasati Lumajang). Vol 6 No.2. Jurnal sains manajemen dan bisnis Indonesia.

Ni Putu Sawitri, dkk. 2013. Pengaruh kualitas pelayanan terhadap kepuasan dan loyalitas pelanggan Tegal Sari Accomodation di Ubud. Vol.7.No.1. Jurnal manajemen,strategi bisnis dan Kewirausahaan.

Novemy Triyandari Nugroho. 2014. Pengaruh kualitas pelayanan terhadap kepuasan dan loyalitas pelanggan (survei pada pelanggan Speedy Telkom di Kota Surakarta. Vol.12 No.2. 114. jurnal Paradigma.

Oni Dian Rachmatiwi, dkk. 2015. Pengaruh kualitas pelayana terhadap kepuasan dan loyalitas pelanggan(survei pada nasabah tabungan PT. Bank Mandiri Persero Tbk.kantor cabang Kota Batu. Vol 19 No.1. Jurnal Administrasi Bisnis.

Resita Widya Putri,dkk. 2015. Pengaruh kualitas pelayanan terhadap kepuasan dan loyalitas pelanggan (survei pada pelanggan Auto2000 Waru Surabaya). Vol.1 No.1. jurnal Administrasi Bisnis.

Rohmat Dwi Jatmiko. 2012. Kualitas pelayanan dan kepuasan pelanggan sebagai anteseden loyalitas pelanggan. Vol.2 No. 01. jurnal manajemen bisnis.

Sanusi, A.2016.metodologi Penelitian Bisnis. Salemba Empat: Jakarta

Sudaryono. 2016. Manajemen Pemasaran: C.V ANDI OFFSET (penerbit Andi).Tangerang

Sugiyono.2016.Metode Penelitian Pendidikan. Penerbit Alfabeta: Bandung.

Tjiptono, F dan Chandra, G. 2017. Pemasaran Strategik. Penerbit Andi: Bandung.

Ustadus Sholohin. 2013. Analisis pengaruh kualitas pelayanan pedagang pasar terhadap tingkat kepuasan pelanggan pasar pahing Kota Kediri.03 No.2.123-134. Cahaya aktiva.

Putra, Y. P., \& Ruhamak, D. (2017). Pengaruh E-Service Quality terhadap E-Loyalty melalui E- Satisfaction pada Pengguna E-Banking di Kota Kediri, (Senima 3), 432-440.

Yunanto, Y. (2017). PENGARUH KUALITAS PELAYANAN DAN DISIPLIN KERJA KARYAWAN BIRO ADMINISTRASI UMUM TERHADAP KEPUASAN MAHASISWA. AKADEMIKA, 15(2), 99-104.

Yuniarti,V.2015.Perilaku Konsumen teori dan praktik. CV. Pustaka Setia: Bandung. 